\title{
Kinsey and the Psychoanalysts:
}

\section{Cross-Disciplinary Knowledge Production in Postwar U.S. Sex Research}

On 3 May 1948, Alfred C. Kinsey penned an open letter to the editors of New Yorkbased society magazine Cue, a leading source of arts and entertainment coverage for well-to-do inhabitants of the metropolis. His letter responded to a recent issue of the magazine "devoted to our research on Human Sex Behavior"-referring, of course, to the publication earlier that year of his Indiana-based team's first major Report on American sexual practices, Sexual Behavior in the Human Male (Kinsey, Pomeroy, \& Martin, 1948). Addressing not, as one might expect, the popular reception of his team's research, Kinsey instead sought to correct a perceived misunderstanding on a rather more specific matter: his position on Freudian theory. Specifically, he responded to a statement

attributed to me, as a direct quotation ... concerning the judgment of psychoanalysts. It should be made clear that I never made such a statement, and that criticism of the sort which is given in the paragraph concerned has never been a part of my thinking. Throughout our research, we have had the abundant cooperation of hundreds of psychiatrists, including psychoanalysts. Many of them are close friends for whom I have considerable esteem. While certain of the generalizations which analysts have previously used, do not seem to be substantiated by our own data, our research confirms many of the most basic of the psychoanalytic concepts. ${ }^{1}$

Requesting that his correction be published "as promptly as possible” to avoid perpetuating both "an injustice to the analysts, as well as an unfair expression of our viewpoint," the timing of Kinsey's outstretched hand towards the psychoanalytic community was particularly meaningful during a year in which American journalists had begun to liken the first "Kinsey Report” to no less a midcentury event than the atom bomb—occasionally even dubbed the “K-bomb” (Igo, 2007, pp. 234, 256; Pomeroy, 1972, p. 342). This was largely due to the revelation that as many as thirtyseven percent of the men surveyed reported at least one adult homosexual experience to orgasm, while up to fifty percent reported homosexual experiences prior to puberty. Such figures problematized not only public perceptions of a homosexual “type,” but also of American male sexuality more broadly, instigating new ways of thinking 
about what "average” Americans did in—and out—of bed (Terry, 1999, pp. 300-301; see also Igo, 2007).

This article delves deeper into the context of Kinsey's letter to Cue to argue for a more nuanced and entangled relationship between the two most significant traditions of scientific inquiry into human sexuality in the early postwar United States, sexology and psychoanalysis. It focuses on Kinsey’s evolving relationship with US-based analysts in the years prior to and following the Human Male Report in 1948 and its even more controversial successor in 1953, Sexual Behavior in the Human Female. While Kinsey was by far the most famous midcentury US sexologist, this analysis also situates his team's research in relation to wider tendencies in North American pre- and postwar sexual science. Identifying some important precursors, this comparison shows how the sexological-psychoanalytic conversation reached well beyond Bloomington, Indiana, and also showcases some of the limits of Kinsey's famed sexual liberalism. It draws attention to conversations across disciplinary boundaries at a time when Freudian traditions of psychoanalysis were rapidly coming to dominate mainstream US psychiatry (Hale, Jr., 1995; Herzog, 2017; Lunbeck, 2003), and complicates common assumptions that Kinsey took an "actively antipsychoanalytic” stance (e.g. Herzog, 2017, p. 135), or that "psychoanalysts were by far Kinsey’s most vociferous critics” (Terry, 1999, p. 24)—such statements tell part, but not all of the story. Finally, it considers some of the implications of viewing scientific knowledge production as always "situated" within wider frameworks of social relations (Haraway, 1988). In the case of late 1940s and early 1950s sexology and psychoanalysis, researchers' views on matters such as religion, homosexuality, and gender identity were particularly important in shaping understandings of "normal” and "abnormal” sexuality.

Kinsey and his team at the Institute for Sex Research (ISR) initially approached psychoanalytic ideas in an open-minded and equivocal manner, as this article demonstrates through reference to the two Reports and unpublished correspondence from the Kinsey Institute archives. His engagement with psychoanalytic modes of inquiry reflected his own commitment, honed during his early training and career as a biologist and entomologist specializing in gall wasps, to the empirical values of natural science (Drucker, 2014). The years between the Male and Female volumes, 
however, saw tensions develop between Kinsey and a number of conservative psychoanalysts, whose views were coming to dominate the 1950s North American psychiatric and psychoanalytic professions. Partly due to theoretical and methodological differences, partly a growing sense of competition, these tensions were compounded by growing public and funding pressure on the ISR team. In contrast, contemporaries such as émigré physician Harry Benjamin, the leading international specialist working with trans-identified patients, continued to evidence the kind of cross-disciplinary openness that had characterized not only Kinsey’s earlier writings, but also dealings between earlier generations of European and North American sexologists and psychoanalysts. In order to situate debates between Kinsey and early postwar psychoanalysts, this article begins by casting a glance backwards to these earlier negotiations, tracing this cross-disciplinary relationship through the ruptures of wartime, when many European practitioners were forced into exile and quite a few emigrated across the Atlantic. It then homes in on the shifting relationship between Kinsey and US-based psychoanalysts from the 1940s to early 1950s, arguing that sexual knowledge production during this period was shaped as much by crossdisciplinary “interpenetrations” (Fuller, 1996, p. 184) as by disciplinary divides.

\section{Sexology and Psychoanalysis from the Old World to the New}

US-based sexologists and psychoanalysts in the 1940s and 1950s could each look back on an at least half a century of professional history, with roots in the medical and scientific professions of late nineteenth-century central Europe, although in the decades after 1900 strong North American branches of sexual scientific and psychoanalytic inquiry had also started to emerge. Sexology's beginnings as a discrete medical-scientific specialization can be traced to a series of psychiatric and criminological studies of the "perversions" by nineteenth-century researchers such as Heinrich Kaan, Richard von Krafft-Ebing, and Cesare Lombroso, resulting in the birth of the scientia sexualis, a post-Enlightenment structure of knowledge shaping understandings not only of human sexuality, but of modern subjectivity itself (Foucault, 1998; Giddens, 1992; Sigusch, 2008). For psychoanalysis the moment of disciplinary establishment came somewhat later; here the foundation of the International Psychoanalytic Association by Sigmund Freud in 1910 serves as a useful 
milestone, following on from Freud’s 1890s work with Josef Breuer treating "hysterical" patients, and the first meetings of the "Wednesday Psychological Society” in Vienna during the 1900s (Makari, 2012, p. 112, 2008; Zaretsky, 2004). These two fields - a more suitable descriptor than "discipline” in these early years, as historians point out (Leng, 2017, pp. 33-34)—shared a strong interest in exploring the nature and pathologies of the human sexual instinct, whether understood in more physiological or psychological terms. Whereas the sexual scientists remained heavily invested in notions of sexual pathologies and abnormalities, however, Freudian psychoanalysis after the fin de siècle sought to broaden the scope of sexual desires and activities that might come within the range of the non-pathological. A key example can be found in differing approaches to homosexuality; as Arnold Davidson shows, whereas many sexual scientists of this era persisted with an older psychiatric "style of reasoning" that viewed same-sex desire as a pathological disturbance of the sexual instinct, perverting its proper function of reproduction, Freud's insistence on seeing the sexual "object” (the person or thing from which attraction proceeds) as fundamentally independent from the sexual "drive" or "instinct," with the two soldered together only through convention, led him to view inversion in terms of developmental difference rather than underlying pathology or degeneracy (Davidson, 2001, pp. 32-35, 72-82, 90). Following the publication of Freud's Three Essays on the Theory of Sexuality in 1905 (Freud, 1962), the relationship between these fields was marked by cautious but genuine enthusiasm, with prominent sexologists including Magnus Hirschfeld and Iwan Bloch lining up among the earliest members of Karl Abraham's Berlin Psychoanalytic Society in 1908, while a first generation of selfdescribed "psychoanalysts” demonstrated their eagerness for cross-disciplinary exchange by publishing in the new German sexological journals of the 1900s to 1920s. Across disciplinary lines, practitioners debated questions such as homosexuality, children's sexuality, the impact of war on sexual and psychological health, and the impact of biology and psychology in shaping sexual desires and behaviors (Fuechtner, 2011, p. 8; Nitzschke, Heigl-Evers, \& Heigl, 1995; Sutton, 2019). Linking these intellectual endeavors were not just shared theoretical concerns, but also a shared methodological commitment to the patient case history (Lang, Damousi, \& Lewis, 2017). 
By the 1920s, though, these scientific traditions increasingly found themselves under pressure to draw boundaries around their disciplinary expertise. While psychoanalysts turned their attention towards cultural historical themes (Zaretsky, 2004, pp. 239242), new developments in hormone research prompted sexologists to more fully investigate the physiology of the sexual body (Bullough, 1994, pp. 120-147; Sutton, 2019; Trask, 2018, p. 183). In the 1930s the National Socialist seizure of power in German-speaking Europe abruptly ended the careers of many of these sexologists and psychoanalysts - many of whom were from central Europe and of Jewish descent—as state-sanctioned anti-Semitism, war, and the Gleichschaltung of Nazi science and medicine brought a swift halt to the first "Golden Age” of European sex research. Psychoanalysis, in particular, was condemned as a “Jewish science” and replaced by the Nazi-aligned Göring Institute, with many practitioners forced into exile abroad (Zaretsky, 2004, p. 245; Frosh, 2005; Fuechtner, 2011, pp. 12-13; Grossmann, 1995, pp. 136-188).

During these crisis years, the United States emerged as the new international center of human sex research. While they occasionally cast a nostalgic glance back to their European predecessors, US-based researchers could also look to strong homegrown traditions of scholarship. The Kinsey team’s Male volume, for example, cites a number of “pioneer studies” by European precursors, including sexologists Magnus Hirschfeld, Albert Moll, Iwan Bloch, and Havelock Ellis, as well as analysts Freud and Wilhelm Stekel (Kinsey et al., 1948, p. 34). Equally, though, the authors looked to North American forerunners, outlined in more detail below. The simultaneous “haunting” by, and subtle distancing of, the Kinsey team's research from that of an earlier generation banished by the Nazis may, as one scholar has recently suggested, have had partly homophobic overtones; in particular, Hirschfeld's same-sex tendencies were well known within the scientific community (Bauer, 2012, pp. 139140). Although such a claim may seem surprising-particularly given the Kinsey's Reports' significance in normalizing same-sex behaviors, as well as indications of Kinsey’s own bisexual desires (Drucker, 2014, p. 2; Jones, 1997)—it aligns with what historians of the midcentury emphasize was a clearly maintained split between researchers' public and private lives: “the emerging liberalism in the science of homosexuality was founded on ways of keeping a safe distance between researchers and their subject” (Wake, 2011, p. 123). In such ways, the Kinsey team acknowledged 
the contributions of earlier European researchers, even as it claimed that its own methods were uniquely capable of reflecting postwar North American sexual behaviors.

The rise of psychoanalysis in the United States, meanwhile, had been spurred along by a series of lectures by Freud and his early Swiss follower Carl Gustav Jung at Clark University in Massachusetts in 1909. It was given further impetus by A. A. Brill's translation of the Three Essays in 1910, and Freud's theories of dreams and development of the clinical "talking cure" enjoyed a growing following among the intellectual avantgarde, particularly along the East Coast (Makari, 2008; Zaretsky, 2004). North American psychoanalysis was further energized during the 1930s and 1940s by émigré practitioners from Nazi-controlled Europe, many of whom rose to leadership positions in US analytic societies and training centers. Karen Horney, a founding member of the Berlin Psychoanalytic Institute, arrived in the US in 1932 and subsequently founded the "Association for the Advancement of Psychoanalysis" and its training institute, the "American Institute for Psychoanalysis"; Hungarian analyst Sándor Radó, who had first met Freud in 1915, emigrated from Berlin in 1931 to direct the New York Psychoanalytic Institute, before cofounding the Columbia University Center for Psychoanalytic Training and Research in 1945/46; and Franz Alexander, Helene Deutsch, Ernst Kris, Hanns Sachs, and Ernst Simmel were among the many others who built successful post-emigration lives across the Atlantic (Fuechtner, 2011; Hale, Jr., 1995, pp. 138-139, 153-155, 217-218; Herzog, 2017, pp. 22-34; Makari, 2012, pp. 119-122; Thompson, 2012). In addition, a number of psychotherapists following the teachings of Freudian breakaway Alfred Adler, such as Sofie Lazarsfeld, relocated to the US during this period (Leng, 2017, pp. 290-306). The intellectual contributions of midcentury US analysts did not simply follow on from their pre-war work, nor did it necessarily follow Freudian orthodoxy. Horney, for example, broke with classical Freudian tenets by moving from a sexualdevelopmental to a more social-cultural model of explanation; Radó—who maintained a close correspondence with Kinsey during these years—challenged Freud's foundational concept of universal bisexuality; while other émigré analysts sought to bypass their own recent traumatic experiences by focusing on more futureoriented topics such as child psychoanalysis (Hale, Jr., 1995, p. 298; Herzog, 2017, pp. 22-34, 63; Makari, 2012; Thompson, 2012; Thompson \& Keable, 2016). During 
these years, US psychoanalysis gained a much wider reach, not least thanks to the growing prestige of its parent discipline of psychiatry, particularly following the widespread treatment of soldiers' psychological disturbances during the two world wars. Swiftly consolidating as the most prestigious and influential branch of North American psychiatry, and a leading force internationally as well, historians agree that the 1950s in the United States represented a "Golden Age” for psychoanalysis — even as it coincided with a decidedly conservative turn by some of the field's leading practitioners (Hale, Jr., 1995, pp. 276-299; Herzog, 2017, p. 5; Lunbeck, 2003). North American-based sex research had also been progressing in leaps and bounds since the early twentieth century, laying the foundations for the more statistical brand of research developed by Kinsey and his team in the 1940s. The ISR researchers explicitly acknowledged the pioneering influence of social reformer and criminologist Katherine Bement Davis, for example, who in 1929 published Factors in the Sex Life of Twenty-Two Hundred Women. Kinsey deemed this work notable not only for its large sample size, but also the neutral phrasing of its questionnaire on such risqué matters as homosexuality and masturbation (Drucker, 2014, pp. 90-92; Terry, 1999, pp. 121-122, 126-135). His team praised psychologist Lewis Terman, famous for his work on intelligence testing, ${ }^{2}$ psychiatrist Gilbert V. Hamilton-who, like Kinsey, had moved from zoological to human study, interviewing one hundred female and one hundred male New Yorkers using questions based in part on Davis's earlier studyand gynecologist and birth control activist Robert Latou Dickinson. Dickinson, who worked with educator Lura Beam, garnered Kinsey’s particular praise in the Male volume as an early adopter of the interview format for sex research, developing a model whereby interview and interviewee "talked as friends talked to friends" (Kinsey et al., 1948, p. 31). Many of these earlier researchers were, like Kinsey from 1941, recipients of funding from the Committee for Research in Problems of Sex (CRPS), founded in 1922 with the support of the Rockefeller Foundation (Bullough, 1994, pp. 109-121; Drucker, 2014, p. 92; Irvine, 1990, pp. 27-28, 34, 226-227; Terry, 1999, pp. 120-158).

Other important homegrown influences on Kinsey’s research included Max Joseph Exner of the American Social Hygiene Association, and Raymond Pearl, whose biometric approach influenced Kinsey’s choice of 100\% group sampling, which aimed for full coverage of individual groups within society rather than a random 
population sample. Although less popular today than random sampling, during the 1930s and 1940s this was considered in line with scientific best practice (Drucker, 2014, pp. 97-102; Igo, 2007, p. 221) Beyond the immediate scientific establishment, the ISR and other postwar sex researchers could also build on the work of the “Committee for the Study of Sex Variants," established by Dickinson in 1935, which had overseen important medical and psychiatric research on homosexuality. Much of this work was conducted by lesbian activist-scholar Jan Gay (born Helen Reitman), who had visited Hirschfeld's famed Institute for Sexual Science in Berlin in the 1920s, and who over ten years collected three hundred lesbian case histories structured along the lines of Hirschfeld's earlier “psychobiological questionnaire.” Gay's role as research assistant was crucial to the 1941 publication Sex Variants: A Study of Homosexual Patterns, officially authored by psychiatrist George W. Henry (Minton, 2010, pp. 18, 20, 33-57; Terry, 1999, pp. 178-219), and although this contribution went largely unacknowledged, such marginalization was not particularly unusual for gay and trans activists of this era keen to be involved in sexual scientific research, but who were "forced to obtain sponsorship and authorial cooperation from physicians and scientists” (Minton, 2010, p. 35). As historians of sexuality have repeatedly shown, even as sexual scientists frequently expressed sympathy for sexual minorities, their clinical encounters with members of those groups involved complex negotiations of “power and pleasure,” as potentially pathologizing impositions of scientific expertise sat in tension with the needs of informants in ways that could have both emancipatory and restrictive effects (Foucault, 1998, p. 45; Terry, 1999, pp. 1718).

By the 1930s, US sex research was also infiltrating into more mainstream discussions via new popular science magazines such as Sexology and journals aimed at both educated lay readers and medical professionals, such the Journal of Sexology and Psychanalysis (1923-1924) or the American Journal of Urology and Sexology (founded 1904) (Bullough, 1994, p. 73). Meanwhile, interdisciplinary approaches for the study of sexuality were being championed by prominent physician-scholars such as Harry Stack Sullivan, a gay psychiatrist known for his “interpersonal theory,” which aimed to place both mental illness and homosexuality in less biological and more sociocultural terms. Sullivan was typical of many psychoanalytically-informed psychiatrists of the 1920s and 1930s in developing progressive, homophile practices 
in his private interactions with patients, even as his public positions on homophobia took a more conservative line; scholars identify a similar split in the work of analytically inclined anthropologists of this era such as Margaret Mead and Ruth Benedict (Wake, 2011, pp. 8, 37, passim). In navigating his own role as a scientist working across public/private divides, Kinsey was following in the footsteps of earlier US as well as European researchers. At the same time, his scientific openmindedness as a scholar who "read indiscriminately across disciplines" and whose objects of inquiry had ranged from plants to gall wasps to human orgasm reflected his unique career trajectory (Drucker, 2012, p. 77, 2014). As Kinsey turned his attention to human sexuality during the 1940s, he sought to use this broad scientific training to build on the work of earlier scholars, developing what he considered to be a superior method of sex research that more fully combined qualitative and quantitative priorities.

\section{The Human Male Report meets the “Golden Age” of Psychoanalysis}

The large-scale surveys of human sexual behavior conducted by the ISR team in the late 1940s were based on long interviews of between 300 and 500 questions and resulted in the collection of erotic histories from over 11,000 Americans. Rather than focusing on the sexual "perverts" and "sex variants" of much earlier research, the Kinsey team initiated a new phase in sexology's history with its explicit focus on the practices of “average” Americans. They stressed the limitations of earlier sex surveys by Davis, Hamilton, and others, arguing that these prioritized college-educated populations, while often contaminating the data with "cases from other social groups" (Kinsey et al., 1948, p. 24). The ISR team sought to remove such problems by surveying entire groups of the population, using punched-card machines to enable swift analysis of mass data sets (Drucker, 2014; Terry, 1999, pp. 297-314). The team repeatedly proclaimed the groundbreaking nature of its approach, conducted in a world very different to that of its sexological predecessors. As the Male volume boldly declares, “Continental European patterns of sex behavior are so distinct from the American ... that no additions of the European to the America data should ever be made” (Kinsey et al., 1948, p. 34). In the Female Report, the authors added that the war itself had changed sexual behaviors, by bringing young American males into 
close proximity with each other through military service, exposing them to the "foreign culture" of Central Europe, and encouraging the "emancipation of the female and especially of the unmarried female in our American culture” (Kinsey, Pomeroy, Martin, \& Gebhard, 1953, pp. 299-300). Perceived geopolitical divides were also evident in European responses to the two Reports, which criticized their "preoccupation with the perceived peculiarities of American national sexual culture and American puritanicalism” (Herzog, 2006, p. 40).

The rapid rise of psychoanalytically trained practitioners within midcentury US psychiatry is a crucial factor in considering why Kinsey felt it necessary to engage so directly with this branch of the human sciences not only his letter to Cue, but also in the 1948 Male Report. The dynamic rise of the “psy-sciences” during this era, including clinical psychology, psychiatry, and psychoanalysis, unfolded as part of a broader expansion of “expert culture” and “psychologization” discourses (Rose, 1996, pp. 224-248; Burnham, John C., 2012, p. 1; Chiang, 2008; Drucker, 2012, p. 79). As psychiatric patients and doctors moved out of specialized mental institutions and into the community, psychological approaches and therapies were increasingly shaping the language, experiences, and self-perceptions of “average” Americans (Minton, 2010, p. 53). As a result, “a peculiarly American dynamic psychiatry,” organized largely along Freudian principles, arose in the United States (Lunbeck, 2003, p. 665). This was, historians agree, a decidedly conservative, family-centered, Christian brand of psychoanalytic thinking, which achieved a high point in the anticommunist, homophobic Cold War climate of the 1950s. Notably, this dominant brand of USbased psychoanalysis placed far less emphasis on sex than had earlier generations of Freudian analysts, as practitioners sought to broaden their field's appeal to middle America (D’Emilio, 1983, pp. 75ff.; Hale, Jr., 1995, pp. 276-299; Herzog, 2017; Zaretsky, 2004, pp. 276-306).

Previous scholarship on Kinsey’s relationship to psychoanalysis has repeatedly emphasized the loud and antagonistic reactions of more conservative analysts to the research being conducted at the ISR. Yet archival correspondence between Kinsey and analytic colleagues from the late 1940s and 1950s reveals that this relationship was based in mutual scientific respect and curiosity, and only gradually took on a more defensive and competitive hue. A tone of warm expectancy characterizes a lecture invitation to Kinsey from the New York-based Association for Psychoanalytic 
and Psychosomatic Medicine in November 1945, for example: "we are extremely interested in hearing your report." 3 A few days earlier, Kinsey had confirmed in a letter to Sándor Radó at Columbia University his willingness to address Radó’s students during a break from collecting histories from New York-based informants, noting that he would be "very glad to meet with the group" and give an account of his team's research. ${ }^{4}$ The lecture was such a success that, a year later, Radó invited Kinsey to again speak to staff and students at the Clinic, including "all physicians enrolled in a graduate training course in psychoanalysis” as well as attendees from the New York Psychiatric Institute and Hospital. ${ }^{5}$ This soon looked set to become an annual affair, with clinic secretary Mary E. Marquette, forwarding to Kinsey a \$50 honorarium, warmly reporting that "everyone enjoyed your visit enormously and we

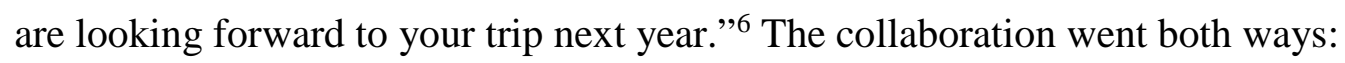
although he returned the check with a friendly affirmation of research integrity_- “we have never accepted fees for lecturing or for writing”-Kinsey explained to Radó that his team made a point of lecturing "only to those groups where we anticipated cooperation in securing histories.” Radó, it seems, was forthcoming, with Kinsey in early 1947 writing that, when the team returned to New York, "I should be glad to make contact with your group and secure more histories of that sort."7 "The psychiatric class," as he later explained in a letter to Marquette, "is a group that we would like to get one hundred percent."8

Radó’s enthusiasm to gain Kinsey as a speaker was hardly an anomaly among his analytic colleagues, and other members of Kinsey's team also participated in such outreach activities. ${ }^{9}$ In 1946 Kinsey agreed to give a paper to the New York Psychoanalytic Institute, again refusing any reimbursement. While such disdain for payments attests to the Kinsey team's self-perception as upstanding and incorruptible scientists, one might also speculate as to the need to dispel suspicions that they were profiting financially from voyeuristic exposés of their sexually explicit materials. ${ }^{10} \mathrm{In}$ 1948, meanwhile, émigré analyst and psychotherapist Emil A. Gutheil, former assistant to Stekel and now a member of Horney's Association of the Advancement of Psychotherapy, wrote to thank Kinsey for his "very interesting and stimulating talk" to the Association's members and friends at the New York Academy of Medicine in April. ${ }^{11}$ President Robert T. Morse of the Washington Psychoanalytic Society similarly reported after a visit from Kinsey that “every one was very enthusiastic 
about your material and the way it was presented.” One audience member even commented on the problem of analytic insularity ("We psychoanalysts ought to have more meetings where we are addressed by some one not a member of our group”); others expressed their enthusiasm by indicating their (or their patients') “willingness to serve as volunteers to be interviewed in case in the future you want to obtain further material from either the professional or non-professional groups.”12 Such sources suggest that many of Kinsey's psychoanalytic contemporaries perceived benefits to learning more about the kind of statistically-oriented research being undertaken in Indiana. They also show that Kinsey’s influence extended well beyond the behaviorist field of clinical psychology, where his work has already been shown to have encouraged mental health experts to develop less pathologizing assessments of the roots and treatment of homosexuality (Chiang, 2008). Even before the 1948 Male volume, mainstream US psychiatrists and psychoanalysts were decidely interested in the research being conducted by the ISR team.

In the wake of this publication, Kinsey’s research resonated both locally and globally. Leading psychiatrists and analysts including Karl Menninger of the Menninger Clinic in Topeka, Kansas and East Coast analyst and Ivy League professor Lawrence Kubie were among those who responded positively, at least to some the volume's findings. Menninger went so far as to proclaim, using decidedly Cold War terminology, that Kinsey's work had “crashed the iron curtain of social hypocrisy” surrounding moral standards of sexuality (Hale, Jr., 1995, p. 297). But Kinsey’s work was also picked up by analysts working further afield. In 1948, Swiss-based analyst Georges Dubal wrote to Kinsey describing how

as a psycho-analyst, specialising in sexual problems, I am greatly impressed by the scope of your research and can see that a study of this kind must be of the greatest value to educators, lawyers, doctors and psychoanalysts. We believe that in Europe there is an equally great need for such a study. ${ }^{13}$

Repeated appeals by other Swiss-based émigré psychoanalysts and self-proclaimed “psychohygienists” Heinrich Meng and Maria Pfister Ammende (wife of psychiatrist Hans Oskar Pfister) to Kinsey to participate in their planned publications provide further evidence that the international analytic community's interest in the ISR research continued into the early 1950s. ${ }^{14}$ 
Nor were these efforts to communicate across disciplinary borders a one-way street. Kinsey endeavored to keep abreast of analytic developments, at least in a lay capacity, taking out a subscription to the new magazine Complex: The Magazine of Psychoanalysis and Related Matters in the early 1950s. This magazine aimed to bring together "articles by distinguished authorities from both sides of the Atlantic and from scholars charting the future course in psychoanalysis and neighboring disciplines."15 An even clearer indication of his openness to psychoanalytic approaches in these years between the first and second Reports was his agreement, albeit cautious, to share some of his team's findings with psychoanalytic colleagues in order to advance their own scientific investigations. In 1951, two years before the Female volume, physician Catherine Bacon of the Institute for Psychoanalysis in Chicago wrote requesting information on orgasm rates among women of various ages. This data, she hoped, would further her work on the sexual psychology of breast cancer survivors: "It has seemed to us that the incidence of frigidity during intercourse is high in this group. We have not questioned these patients as to orgasm in other ways than through intercourse.”16 Thanking her for her interest in his team’s research, Kinsey cautioned that the data on the frequency of female orgasm during coitus "are not in final form" but agreed to give some general estimates, albeit "with the understanding that these are not to be published and that they may depart considerably from calculations that we will have ready for print very soon.”17 (It is notable that this correspondence centered on female orgasm, for when the Female volume appeared in 1953 it was precisely such taboo areas of female sexuality that were targeted by many of Kinsey's critics, including conservative analysts.) As late as 1954, moreover, when relations with analytic colleagues were otherwise starting to fray, Kinsey maintained at-leaston-paper membership of Horney’s Association. ${ }^{18}$ Taken together, such sources paint a picture of America's now-leading sexologist not as an embattled opponent of psychoanalytic developments, but an interested and engaged observer of this field.

This is not to say that Kinsey and his team wholeheartedly embraced psychoanalytic ideas - particularly when it came to endorsing them in published form. Here, too, we see evidence of the public/private split that historian Naoko Wake identifies as characteristic of the work of many midcentury researchers working on sexual topics, such as Sullivan, Mead, and Benedict, where an openminded approach to scientific methods or sexual practices in private correspondence or clinical conversations 
frequently gave way to more conservative public and published utterances (Wake, 2011). Yet even here, a nuanced reading of the Kinsey team's writings is in order, for the Male volume accepted a number of Freudian assumptions without hesitation, such as the idea of sexuality "as a component that is present in the human animal from earliest infancy." On the other hand, the ISR authors rejected several key tenets of psychoanalytic theory, such as the Freudian insistence on "a pre-genital stage of generalized erotic response that precedes more specific genital activity” (Kinsey et al., 1948, p. 180). More broadly, they disagreed with the definition of the "sexual" employed by the Freudians, arguing that this constituted

a considerable extension of both the everyday and scientific meanings of the term [...], and we are not now concerned with recording every occasion on which a babe brings two parts of its body into juxtaposition, every time it scratches its ear or its genitalia, nor every occasion on which it sucks its thumb. (Kinsey et al., 1948, p. 163)

The team also used its interview-based data to argue against the psychoanalytic idea of a "latency" period, instead characterizing apparent sexual inactivity during later childhood as dependent on social circumstances: "such inactivity results from parental and social repressions of the growing child (Kinsey et al., 1948, p. 180).

During these years disparities were starting to crystallize at the level of method as well as theory. The Male volume marked a decisive shift toward quantitative sex research that, in seeking to track the behaviors of entire groups within the American population, was far less concerned with questions of abnormality and deviance than earlier generations of psychiatrists and sexologists. Although the ISR team's methods had precursors in questionnaires developed by Hirschfeld, Davis, Dickinson and others, their work placed far more emphasis on statistically computing data from thousands of "healthy" informants (Drucker, 2014, pp. 89-107). A sense of technological superiority led them to downplay other modes of inquiry, included those of psychoanalysis. These criticisms became stronger over time, but even the earlier Male volume argues that the "pioneer studies” of prewar Europe lacked "any precise or even an approximate knowledge of what average people do sexually”:

They never knew what things were common and what things were rare, because their data came from the miscellaneous and usually unrepresentative 
persons who came to their clinics (Freud, Hirschfeld, et al.), or from persons from whom they happened to receive correspondence (Ellis), or from limited numbers of persons whom they interviewed in elaborate detail (Kinsey et al., 1948, p. 34).

Here the ISR team attacks the small sample size and pathologizing context of early psychoanalytic and sexological studies, with their basis in "subjective” case histories rather than more “objective” statistical data. This was, however, not a flawless comparison, particularly given the similarities between the ISR's own one-on-one interview methods and the established genre of the clinical case study. ${ }^{19}$ The Kinsey team's claims to be pursuing a more objective, "value-free” (on this term, see Terry, 1999, pp. 7-8) sexual science were also deeply undermined, as scholars have shown, by its own exclusionary practices. The two Reports were heavily skewed towards middle-class subjects, for example (although this was somewhat rectified in the Female volume following criticism of the Male study), and they also left out all data on African American women and men, ostensibly on the basis that insufficient histories had been collected to reach meaningful conclusions (Bauer, 2012, pp. 134, 139; Drucker, 2012, p. 78; Irvine, 1990, pp. 20, 37; Reumann, 2005, pp. 114-118; Terry, 1999, pp. 299-300). In such ways, the ISR's research replicated much of the class blindness of previous sexual scientific research, as well as the racialized assumptions of whiteness infusing earlier investigations of "normal” and "abnormal" sexuality (Carter, 2007).

A central methodological conflict was thus emerging between the "individuating knowledge” of the medical gaze characteristic of both early sexology and psychoanalysis—prioritizing the individual, peculiar, and unique—and a modern form of "standardizing knowledge” focused on numbers and averages. The ISR team's statistical approach aligned with the much broader trend in midcentury US scientific and popular discourse towards ideas of the "norm" and the "normal," which scholars have shown produced all manner of attempts to map the "average” American man and woman (even including the creation of two statues, dubbed "Norm" and Norma," seen to embody "typical” American bodily proportions) (Cryle \& Stephens, 2017, pp. 4, 294-332). Competing understandings of “normal” sexuality can, moreover, be identified as a key factor conceptually separating the Kinsey’s team's 
research on the one hand, with its emphasis on "norms" based in statistical frequency, from mainstream psychoanalysis, which understood "norms" primarily in terms of social values (Chiang, 2008, pp. 309, 313; Cryle \& Stephens, 2017, pp. 333-351). The Kinsey team’s approach—“blunt, practical, and obsessed with numbers”—was seemingly more in line with a modern scientific rationality than "the Freudian mystique of sexuality” (Irvine, 1990, pp. 28, 65), with its focus on neurotic individuals and unconscious fantasies. Yet these distinctions were not cleancut; as already noted, the ISR's detailed interview method impinged on, and even replicated in some respects, the kind of one-on-one clinical encounters prioritized by psychoanalysis. As one historian has recently argued, the Indiana researchers showed contemporary analysts that other fields, too, could successfully take "ordinary people’s experiences seriously” (Herzog, 2017, p. 58). At the same time, by claiming that their methods represented a rationalized empiricism, the ISR team positioned sexuality as an appropriate object of scientific scrutiny in ways that signaled shifting ideas about what constituted "legitimate knowledge” (Foucault, 1998, p. 72) among both scientists and the American public. These theoretical and methodological shifts helped to drive a growing wedge between sexological and psychoanalytic approaches by the end of the first postwar decade.

\section{Growing Tensions: The Human Female Report and the Conservative Psychoanalytic Response}

Published on 20 August 1953, just three years before Kinsey’s early death (partly from overwork) at the age of 62, the Female volume was widely regarded as even more shocking than its Male counterpart for the way it challenged widespread views on female sexuality. Its publication was even hailed by some as “K-Day," in a continuation of earlier atomic bomb analogies (Pomeroy, 1972, p. 343; Drucker, 2014, p. 143; Gordan, 2014; Weber, 2010, p. 189). By this stage Kinsey had become, as staff member Wardell B. Pomeroy later remarked, “one of the most widely known scientists of this century, a household name in the United States” (Pomeroy, 1972, p. 3). The second volume offered a sharper attack than the first on the role of JudeoChristian religious traditions in perpetuating sexual prudery, and unsettled understandings of gendered sexual behaviors with a graphic exposé of the intimate 
practices of American girls and women, including masturbatory, premarital, and same-sex activities (Griffith, 2008, p. 365; Irvine, 1990, pp. 63-64). As one journalist noted at the time, "My opinion is that the American public, both male and female, was afraid to read the report on female sexuality because it was afraid to confront what it knew it would find there-confirmation of the unsettling idea that in their sexual behavior women are just as good, or bad, as men." ${ }^{20}$ Not surprisingly, some of the most vocal critics came from the world of organized religion, with one Catholic commentator describing the Report as "a direct frontal assault upon Christian civilization and a dirty, beastly attack upon American womanhood." ${ }^{21}$ The Female volume also, however, provoked a series of well-publicized encounters between Kinsey and conservative psychoanalysts, pointing to an increasingly embattled stance between these camps as the 1950s progressed.

Analysts of this era were working to establish professional reputations within a conservative McCarthy-era climate that emphasized traditional family values and normative gender roles. Perceptions of gender in “crisis” were spurred along by women's mass involvement in the war mobilization during the 1940s and the rise of urban queer subcultures, particularly in coastal cities such as San Francisco and New York, while communism became increasingly aligned with homosexuality in the popular imagination (D’Emilio, 1983; Irvine, 1990, pp. 32-33, 54). During these years, mainstream North American psychoanalysis and, by extension, psychiatry became increasingly homophobic, pathologizing, and moralizing (Chiang, 2008, pp. 301-302; Dean \& Lane, 2001; Hale, Jr., 1995, pp. 298-299; Herzog, 2017; Terry, 1999, pp. 307-314). This conservative shift was infused with anti-Semitic elements, as psychoanalysts struggled to lose their reputation as practitioners of a "Jewish science” and appeal to a middle American Christian conservative public. For such reasons, Dagmar Herzog in her recent book Cold War Freud diagnoses a thoroughgoing “Christianization” of North American psychoanalysis in these years, born out of the "peculiar mix of revived religiosity, secularization-cumpsychologization, and greater religious pluralism that defined the postwar moment” (Herzog, 2017, pp. 12, 22). Against this backdrop, the Female volume prompted a much fiercer reaction from analysts than its predecessor had done.

The American reading public_-including the millions who learned of the Kinsey findings primarily via the mainstream media—-knew roughly what to expect from this 
second volume after the sensation surrounding the Male Report: "Kinsey and his 'book on sex' were so fully saturated into 1950s America that merely saying his name became code for speaking of sexuality” (Weber, 2010, pp. 189-190; see also Griffith, 2008, p. 363). It was controversial both because many readers were afraid of what it might reveal about American women in an era already deeply worried about changing gender roles and heterosexual practices, but also due to its radical questioning of whether gender was even the best way of examining sexual difference. "By the end of the book," as one scholar observes, "Kinsey finds that divisions of human sexual difference other than gendered ones make the most sense” (Drucker, 2014, p. 144). In 1954, controversy surrounding the volume led Kinsey to lose his central funding stream from the Rockefeller Foundation's Medical Division, which had funded the ISR via the CRPS since 1941 (Drucker, 2014, pp. 110, 167; Pomeroy, 1972, pp. 10, 80). Although ostensibly on tax grounds, even contemporaries recognized this as a cover for rising conservative pressures on the organization, including suspicions that Kinsey was a communist sympathizer, threatening national security by exposing American sexual practices. Pomeroy later observed, not without bitterness, that "The truth was that the Foundation had simply quit, under pressure and out of fear ... the Foundation could not take the heat” (Pomeroy, 1972, p. 380; see also Drucker, 2012, p. 93; Irvine, 1990, p. 66; Jones, 1997, p. 723).

Even as some progressive commentators celebrated the second Report for further opening up public discussions of sexuality, it also came under sustained attack, on both methodological and moral grounds, including from statisticians, psychiatrists, sociologists, and psychoanalysts. Psychoanalysts objected particularly to the Report's treatment of homosexuality, masturbation, vaginal versus clitoral orgasm, and the relationship between a biological sex drive and psychological factors such as love. These debates, historians have shown, were as much about professional status as intellectual differences, as analysts saw their claims to expertise threatened by Kinsey-style knowledge production, and lashed back along socially conservative lines. Seeking to further their influence within both the psychiatric profession and US society, many adopted a puritanical, desexualizing, and "rationalized" approach to the study of the human unconscious, firmly infused with the "misogynist and homophobic views for which they have become so justly notorious” (Herzog, 2017, p. 55, see also 56-86; Hale, Jr., 1995, pp. 296-298; Terry, 1999, pp. 297-314). 
In such ways, the "Golden Age” of US psychoanalytic dominance, which lasted from the 1950s through to the early 1960s, coincided with the closing down of some of the more progressive and radical elements of prewar analytic thought. Making analytic ideas and therapies more socially palatable in this conservative climate required a deliberate downplaying of psychosexual explanations, including early Freudian keystones such as the Oedipal complex and the libido. This conservative turn becomes particularly evident when one compares analytic attitudes to homosexuality before and after the war. From the 1900s to the 1920s, Freudians developed a wide spectrum of approaches to same-sex desire: while some, such as Isidor Sadger of Vienna, had worked along normative lines to develop a "cure” centered on heterosexual conversion, others pursued more liberal lines of thought, critiquing the intolerance of society rather than the homosexual condition. Freud himself had sat somewhat on the fence earlier in his career, but later moved towards accepting homosexuality as a nonpathological variant (Lang \& Sutton, 2016). In contrast, many outspoken postwar US psychoanalysts by the midcentury, including Edmund Bergler, Irving Bieber, and Charles Socarides, took a decidedly pathologizing approach to the clinical treatment of homosexuality (Bergler, 1956; Bieber, Dince, Drellich, \& Grand, et al., 1962; Socarides, 1960; see also Hale, Jr., 1995, pp. 298-299; Herzog, 2017, pp. 62-65, 70, 73; Terry, 1999, pp. 297-314).

Conservative analysts also objected to the Reports’ overly “zoological” focus. Disparaging references to Kinsey's earlier entomological career highlighted the ISR's focus on physical "sexual outlets," especially orgasm, rather than more psychological motivations for sexual behavior, such as love, tenderness, intimacy, or unconscious factors such as phobias and fantasies. Even the once sympathetic Menninger, now President of the APsaA, declared that “Kinsey’s compulsion to force human sexual behavior into a zoological frame of reference leads him to repudiate or neglect human psychology, and to see normality as that which is natural in the sense that it is what is practiced by animals” (cited in Hale, Jr., 1995, p. 298). Kubie, too, criticized the ISR for failing to consider psychological factors that might produce "frank details ... about the gasoline and fuel that actually drives the engine in sexual instinct" (in Drucker, 2012, p. 83). Such criticisms extended across disciplinary lines: the analytically well-informed anthropologist Mead was among those to declare the current trend in U.S. sex research towards "atomizing” sex to be "excremental” (in 
Terry, 1999, p. 305; see also Chiang, 2008, p. 300). The force of analytic criticisms of Kinsey during these years is evident from Pomeroy's later recollection of Hungarian émigré analyst Franz Alexander taking the floor at a conference at which Kinsey was speaking, where he "urged all psychiatrists to reject every one of his conclusions" (cited in Hale, Jr., 1995, p. 298; Pomeroy, 1972, p. 367). This practice of confronting Kinsey in public forums became something of a pattern for 1950s analysts.

Contrasting their own psychological focus-what one historians dubs "the love doctrine” (Herzog, 2017, p. 66)—with Kinsey’s “zoological” one was rhetorically powerful; it also helped to further distance psychoanalysis from socially spurious psychosexual explanations.

Amidst this growing conservatism, the respectful relationships that Kinsey and his team had cultivated with analysts such as Radó and Menninger during the late 1940s began to disintegrate in the years following the Female Report. Psychoanalysts did not take a singular, hegemonic stance on the Kinsey findings; one notable exception was a positive review by psychoanalytic psychologist Erich Fromm, who, while noting the criticisms of some of his analytic colleagues, insisted that "the Kinsey Report with its wealth of data on sexual behavior constitutes an invaluable source of information for the student of social psychology and particularly of character (Fromm, 1955, p. 304). However, conservative analysts certainly counted among some of Kinsey's staunchest opponents. The New York-based Bergler, for example, loudly rejected the Reports' findings on the extent of masturbation in the population, and was appalled by the suggestion that homosexuality be considered a "normal" rather than pathological variation. This stance, he argued (as earlier analysts such as Sadger had also done) stood in the way of therapeutic intervention. Bergler also objected to the Kinseyan finding that female sexual desire was of a comparable strength to male. Such homophobic and misogynistic pandering to homegrown religious conservatism played into wider Cold War anxieties, evident from Bergler's warning that the Kinsey findings might "be politically and propagandistically used against the nation as a whole in a whisper campaign” (Reumann, 2005, p. 46; Bergler, 1956; see also Bullough, 1994, pp. 169-170; Chiang, 2008, pp. 301-303; Hale, Jr., 1995, pp. 296-299; Herzog, 2017, pp. 56-86; Irvine, 1990, pp. 34-66; Terry, 1999, pp. 297-314). 
Somewhat paradoxically, by the late 1960s pressure from feminist and gay rights activists against this dominant brand of conservative psychoanalysis, together with a growing sense that analytic approaches in general were scientifically outdated in an age of rapid biomedical and pharmacological advancement, helped to end the field's "golden age” within US psychiatry. By this stage, a number of more progressive psychoanalytically-oriented psychiatrists such as Robert Stoller and Judd Marmor had also joined gay activists in condemning the inclusion of homosexuality in the Diagnostic and Statistical Manual of Mental Disorders. Even so, homophobia remained so entrenched within the psychoanalytic profession that not until 1991 did the American Psychoanalytic Association (APsaA) pass a non-discrimination declaration to permit the certification of gay or lesbian analysts, some eighteen years after homosexuality was removed from the DSM (Hale, Jr., 1995, p. 299; Herzog, 2017, pp. 12, 67-86).

Kinsey, for his part, also dug in his heels during these years, helping to shore up a renewed posexological-psychoanalytic divide. For one thing, he refused to accept the now-prominent analytic view that masturbation was a sign of pathology. (This, like conservative analytic views on homosexuality, represented another shift away from more liberal prewar psychoanalytic approaches, which had deemed masturbation and other infantile excitations of the "erogenous zones" part of normal sexual development [Bullough, 1994, p. 169; Hale, Jr., 1995, p. 297; Hegarty, 2013, p. 121]). In the Female volume, the ISR team trace their own evolving standpoint on this issue, noting that whereas they had once been "inclined to accept the Freudian interpretations" regarding self-stimulation, their greater understanding of the "basic physiology of sexual response" now led them to define sexual behavior in narrower terms, as “a unique combination of elements which appears only when an animal has coitus or when it becomes involved in activities which, at least to some extent, duplicate some aspects of coitus” (Kinsey et al., 1953, p. 134). The Bloomington researchers also continued developing their sociocultural critique of the latency phase, arguing that this "seems to be a period of inactivity which is imposed by the culture upon the socio-sexual activities of a maturing child, especially if the child is female.” Failure to recognize this fact, they argued in a superior tone, had prevented previous researchers from realizing the full extent of female sexual capacity (Kinsey et al., 1953, p. 116). Such findings elicited sharp responses in turn: a book that Kinsey critic 
Bergler co-authored with Chicago physician William S. Kroger in 1954, bearing the unsubtle title Kinsey's Myth of Female Sexuality: The Medical Facts, set out twelve alleged "false premises" in Kinsey’s study, beginning with the understanding that “normal people will [not] tell the truth about their sex life” (Kroger \& Bergler, 1954, p. 5; Weber, 2010, p. 191).

Questions of method also continued to drive a wedge between the Kinsey team and mainstream analytic psychiatry during these years. In the Female volume's foreword, CRPS chairpersons Robert M. Yerkes and George W. Corner acknowledged as much, suggesting that Freud was "not fitted by nature or training" to carry out the "great task of fact-finding” that the proper scientific pursuit of his theories would demand, in contrast to "Alfred Kinsey, the laboratory- and field-trained biologist” (Robert M. Yerkes and George W. Corner, “Foreword,” in Kinsey et al., 1953, p. viii). This prioritization of the physiological and empirical also shapes the contents of the Report. Taking to task Freud's theory that female psychosexual maturation rightfully proceeds from clitoris to vagina, the Kinsey team argue that this reasoning is flawed because "there are no anatomic data to indicate that such a physical transformation has ever been observed or is possible” (Kinsey et al., 1953, p. 582; cf. Freud, 1962). The researchers instead cite their own use of vaginal sensitivity measurement to disprove this thesis — and ultimately, as Donna Drucker observes, to argue for “men's and women's anatomical sexual likeness” (Drucker, 2014, pp. 147, 156). For the Kinsey team, then, the measurement of physiological responses constituted a key source of scientific legitimacy in an era of technological modernity, and a means of drawing boundaries around their own expertise in the face of analytic competition.

Kinsey's correspondence with analytic colleagues during these years reflects these growing tensions, albeit in a less confrontational manner than his well-known public encounters with Bergler and others. A series of letters exchanged in the early 1950s with Japanese researcher Takahashi Tetsu—who himself espoused a decidedly interdisciplinary approach as both director of the Japanese Sexological Association and president of the Japanese Psychoanalytic Society—offers nuanced insights into Kinsey's evolving stance. The psychologically trained Takahashi regularly supplied Kinsey with Japanese research materials, and paid his respect to the Indiana-based researcher in personal correspondence as someone "whom we Japanese Sexologists 
respects as a great senior."22 Kinsey’s replies, despite their friendly tone ("I have acquired considerable esteem for the objectivity of the research which you and various others have done in Japan”), suggest a growing criticism of competing research methods. As early as 1951, he issued Tekahashi the following warning:

I hope that your research workers on sex are not going to be influenced too much by psychiatric theory. In regard to each part of that theory the scientist must carefully inquire how thoroughly the theory is supported by objectively procured data. ${ }^{23}$

Even as Kinsey's interest in non-Anglocentric approaches can be deduced from his team's employment of translators (including, as he assured Tekahashi, a man able to read some Japanese), such statements not only shore up his skepticism regarding the methodological flaws of psychoanalysis ("psychiatric theory), but also reveal a racially infused condescension regarding the corruptibility of non-western sex research. $^{24}$

The extent to which his relationship with contemporary analysts had soured in just a few years is further evidenced in a letter penned by Kinsey shortly before his death in 1956 to Texas-based psychologist Karl M. Dallenbach. Responding to an article by that author comparing phrenology and psychoanalysis in the American Journal of Psychology, Kinsey praised Dallenbach for drawing attention to analytic matters of ongoing concern:

I think it excellent that you should have pointed out some of these things. We have been dismayed for many years, in our constant contact with psychoanalysts, to discover how few scientifically established data lie back of their deep convictions, and above all, how lacking they are in any scientific evidence that their techniques have effected "cures."25

Yet Kinsey’s sharpened criticism of mainstream psychiatry as lacking scientific credentials contrasted with the self-assessment of many psychoanalysts themselves during these decades. As early as 1938 Chicago-based émigré analyst Franz Alexander had declared to the APsaA that New World psychoanalysis would likely take on a "more scientific character," based more in observation and less in theoretical obscurities, suggesting a shared embrace of the kind of scientific 
modernity espoused by Kinsey’s team (Alexander, 1938). Kinsey’s methodological quibbles with psychoanalysis were also based to an extent on willful blindness to shared practices, such as the aforementioned similarities between the psychoanalytic case study and the ISR team's interviews. Nonetheless, perceived differences of method marked an increasingly unbridgeable gap not only between Kinsey and the 1950s psychiatric profession, but also between the broader fields of North American sexual science and psychoanalysis in the decades that followed. In such influential studies as William Masters and Virginia Johnson’s Human Sexual Response (1966), interviews, particularly with married couples, continued to play a significant role, but they now sat alongside much more experimentally oriented modes of investigation such as phallometry, aimed at precisely quantifying the extent of physiological responses to sexual stimuli (Bancroft \& Graham, 2014; Masters \& Johnson, 1966). These and other post-Kinseyan sexologists placed a growing emphasis on empirically measurable approaches to human sexuality, viewing these as at least as significant as psychological modes of inquiry.

\section{Situated Knowledges and Cross-Disciplinary Encounters Beyond Kinsey}

Previous accounts of Kinsey's clashes with the psychoanalytic profession have emphasized their competing definitions of sex-viewed as either predominantly physiological (Kinsey) or psychological (the analysts)—as well as the differing stances on questions such as homosexuality outlined abooove, with Kinsey's attempts to normalize same-sex experiences through statistical data contrasting with the psychoanalytic homophobia of Bergler and others. In these accounts, Kinsey generally shines through as a liberal beacon in a conservative medical-scientific profession dominated by puritanical values. This picture requires further complicating, though, in light of sources showcasing both the limits of Kinsey's religious liberalism — particularly in regard to Judaic traditions — and his position on gender diversity, which was less liberal than that of other sexologists of this era.

The shifting profile of mainstream US psychoanalysis towards a puritanical Christian model by the 1950s points to the importance of religion in any account of Kinsey's relationship with this field. In recent years historians have delved deeper into 
Kinsey’s interactions with American Christian and Jewish groups, challenging assumptions that Kinsey was straightforwardly antagonistic towards organized religion for its hypocritical and negative influence on dominant attitudes toward sexuality, while deepening our understanding of clerical responses to his work. Kinsey, although "scrupulously secular" in his own convictions, engaged in a number of mutually collaborative engagements and lengthy correspondences with liberal Protestant and Jewish religious leaders, even convincing some to supply their own sexual histories to his team. As this research shows, such collaborations helped to open up religious discussions of sexual ethics even well beyond his death, and complicate narratives of a singular postwar "sexual revolution" centered on the late 1960s, pointing to shifting attitudes in American society well before the Woodstock era (Griffith, 2008, pp. 350, 372-373, 377; see also Gordan, 2014).

The emphasis of analysts such as Bergler and Bieber on Christian, middle-American values, meanwhile, represented a notable shift in a field with strong historical associations with Jewish researchers, from Freud and many early members of the Vienna and Berlin Psychoanalytic societies to the émigré analysts who played a leading role in North American analytic societies of the 1940s and 1950s. This religious situatedness was for many practitioners more about familial-cultural connections than individual religious practice, but it did not go unremarked in the Kinsey Reports. These tread a complex and at times contradictory line between acknowledging more positive elements of Jewish sexuality_including paying attention to differences between Orthodox and more liberal variants in a manner unusual for non-Jewish researchers of this era (Gordan, 2014)—while at other times engaging in arguments bordering on the anti-Semitic. The latter are rarely mentioned in scholarly accounts of Kinsey's research, yet they influenced his assessment of psychoanalysis in ways that undermined his claims to be conducting strictly empirical, "value-free” research.

At one level, Kinsey carefully positioned his work against religious prejudice and the recent history of the Holocaust, describing Orthodox Jewish men's sexuality in the Male volume as "especially interesting, in view of the diametrically opposite opinion which recently stirred a considerable portion of Europe against the Jews as a race” (Kinsey et al., 1948, p. 485). Although he later concluded that there were bigger 
differences between the sexual behaviors of devout and non-practicing members of the Jewish and Christian faiths than between differing religious traditions, particularly regarding premarital chastity (Kinsey et al., 1953, p. 324; Griffith, 2008, p. 364; Gordan, 2014), Kinsey made an exception in the case of Orthodox Jewish males. This group, he found, evidenced a lower physiological sexual response or "total sexual outlet": "the sexually least active individuals in any age and educational group are the Orthodox Jews (who are the last active of all), the devout Catholics, and the active Protestants (in that order) (Kinsey et al., 1948, pp. 469-476 at 469). Despite this distinction, some Modern Orthodox thinkers viewed the Reports less as an attack on their community than as provoking important discussions about postwar sexual norms, and even as an opportunity to highlight, as Rabbi Norman Lamm declared, “the openness and frankness of Jews in talking about sex.” Viewed in this way, the Kinsey Reports represented an opportunity to celebrate Jewish traditions of sexual self-control and mutually pleasurable heterosexual intercourse. Against a Cold War backdrop in which virile heterosexual masculinity was prized as central to American citizenship, observes Rachel Gordan, Kinsey’s Reports at once "suggested a normalization of non-Orthodox Jews" while also placing them "outside of the sexual and the American mainstream” (Gordan, 2014).

A far less tolerant approach is evident, however, where Kinsey aligns more conservative or Orthodox Jewish traditions with the outdated American Puritanical sexual ethic maligned elsewhere in the Reports, arguing that both were proscribed by older Talmudic traditions (Gordan, 2014; Kinsey et al., 1948, p. 465). He had also, during earlier stages of his career, voiced opinions with overtly anti-Semitic implications, such as his support for the 1924 Immigration Act that had prevented many European Jews from resettling in the United States (Hegarty, 2013, p. 121). Anti-Semitic lines of thinking infiltrated his later sex research as well, with the Female volume dismissing Freudian criticisms of adult masturbation as not only “infantile” or "immature," but also as "perpetuat[ing] the Talmudic traditions which are now being fortified with a new set of terms which appear to have scientific status” (Kinsey et al., 1953, pp. 170-171). While Kinsey also levelled criticisms of stultifying sexual prudery against conservative Christian traditions, here his critique is directed both at conservative Judaism and also, by association, at the scientific legitimacy of psychoanalysis. Such examples represent an important limitation on his much- 
vaunted scientific openmindedness, showing how this was shaped by his own situatedness as a secular researcher of Protestant background writing for a largely Christian-identified American public.

A further limitation can be found in his views on transgender individuals. Kinsey's efforts to normalize homosexuality as a typical part of the average American male's experience did not, scholars have shown, extend to trans identities, especially when it came to endorsing hormonal or surgical interventions. Kinsey ignored cross-dressing and trans identities in the Male volume, but began to take an interest in interviewing transvestite and transsexual subjects from the late 1940s, when he also started collaborating with trans activist-scholars such as Louise Lawrence. Lawrence had the job of convincing Kinsey, as she recorded in her unpublished autobiography, that transvestism "is much more common than most of us, even prominent doctors, are willing or able to admit," and she introduced him to a wide array of cross-dressers and transsexuals with a view to recording their histories (Meyerowitz, 2001, pp. 74-80; Lawrence cited at 75). Yet while this collaboration suggests that Kinsey's stance was broadly sympathetic, his commitment to a definition of healthy sexuality based around genitalia and the capacity to orgasm led him to advise against surgery for trans-identified individuals. Instead, he recommended that they enter into homosexual relations - which, understandably, his trans informants considered an unsatisfactory solution. Here Kinsey "hit the limits of his sexual liberalism," as one scholar observes, "in which he approved of all sexual variations that did not involve coercion.” Instead, he insisted on a behaviorist model of gender identifications that viewed males as more vulnerable to crossgendered practices due to a presumed greater sensitivity to psychological conditioning (Meyerowitz, 2001, pp. 89, passim). This behaviorist view of trans phenomena put him at odds with contemporary psychoanalysts.

Midcentury analysts picked up on prewar analytic discussions of trans identifications in the 1950s, particularly following the mass media attention surrounding figures such as Christine Jorgensen, who underwent gender confirmation surgery in Denmark. They continued to insist, as their prewar colleagues such as Emil Gutheil and Wilhelm Stekel had done, that crossgender identification was a psychological condition with roots in early childhood experience (Gherovici, 2017, pp. 6, 41-62). In 
the decades that followed, the relationship between mainstream psychoanalysis and transpeople was often marked by distrust, despite many being actively involved in some form of psychotherapy (Gherovici, 2017, p. 24). For different reasons, then, mainstream analysts shared with Kinsey a rejection of the idea of surgery for trans individuals-Kinsey on behaviorist grounds, while analysts such as Radó saw surgery as too focused on physiological rather than psychological factors (Radó, 1940; Chiang, 2008, pp. 307-308; Meyerowitz, 2001, pp. 73-74, 82-84, 88-89).

Kinsey's conservative position on this matter distinguished him from a number of sexological colleagues. In particular, prominent émigré endocrinologist Harry Benjamin exhibited a commitment to human physical bisexuality as a foundation for trans medicine that seemed to be supported by the latest endocrinal research, and led him to strongly support surgical pathways. A frequent visitor to Eugen Steinach's labs in Vienna in the 1920s and 1930s, which had overseen groundbreaking research into the sex hormones, Benjamin was responsible for introducing the concept of "transsexualism" to American medicine from the 1950s, and one of the key figures in developing surgical gender confirmation procedures in that country (Ekins, 2005; Gherovici, 2017, pp. 56-57; Meyerowitz, 2002; Sengoopta, 2000). Benjamin and others dealing with trans-identified patients, such as sex writer and educator David Cauldwell (author of a prominent 1949 article in Sexology magazine on "Psychopathia Transsexualis”), also continued to engage in a more dialogic relationship with psychoanalytic findings and clinicians into the 1960s and beyond than Kinsey and his team. This was not an uncomplicated stance: intent on looking for physiological answers, Benjamin at times rejected psychotherapeutic intervention as a "waste of time" and inadequate to the task of explaining trans identities (Benjamin, 1954, p. 228). Yet he also argued that psychiatry could provide important support for patients as they underwent hormonal and surgical treatments. To this end, he collaborated with analyst Robert Stoller in establishing the pioneering Gender Identity Center at UCLA in the early 1960s (Gherovici, 2017, pp. 55-57 on Benjamin and Cauldwell and 57-59 on Stoller; Chiang, 2008; Ekins, 2005, p. 309; Meyerowitz, 2001, pp. 78-80). Kinsey himself worked closely with Benjamin at various pointswhose papers are now housed at the Kinsey Institute archive-and even referred to his New York-based colleague the latter's first “transsexual” patient in 1948; later, he also sought out interviews with Benjamin’s famous patient Jorgensen. Unlike 
Benjamin, however, Kinsey published only a few paragraphs on transvestism in the Female volume and did not follow his colleague in supporting gender confirmation surgeries. Kinsey's treatment of Jewish and transgender issues showcases both his growing rejection of psychoanalytic approaches as the 1950s progressed, but also some of the limitations on his famously liberal stance. These examples, and the brief comparison with Benjamin, serve as a useful reminder that Kinsey's research, however pioneering, must not be allowed to stand in for the entirety of midcentury sexual science, and that his own shifting relationship to mainstream psychoanalysis was not identical with that of his sexological contemporaries.

\section{Conclusion}

Examining the cross-disciplinary interpenetrations that helped to shape new forms of knowledge about sexuality across the human sciences in the middle decades of the twentieth century involves interrogating the shifting and overlapping "styles of reasoning” (Davidson, 2001, pp. 32-35, 125ff.) employed across these fields. New forms of sexological and psychoanalytic knowledge continued to be "haunted" by older traditions of disciplinary knowledge, even as they were shaped by the postwar social positioning of the human actors involved in their production. Understanding how ideas of sexuality were transformed as the center of international sex research moved from Europe to the United States thus requires not only attending closely to such influential texts as the two Kinsey Reports, but also the broader intellectual and transnational forces out of which these evolved. These ranged from personal and professional experiences of war, exile, and dislocation, particularly in the case of many émigré analysts, to the increasingly conservative religious, social, and political values shaping the early Cold War USA, with its emphasis on polarized gender roles and fears of the communist "other." Such was the backdrop for the rapid ascendancy of a conservative psychoanalytic strand within postwar US psychiatry, as well as for the mainstream appeal of the empiricist style of sexual scientific reasoning represented by Kinsey and the ISR team.

After decades of competition between sexologists and psychoanalysts over questions of etiology, diagnosis, and treatment, the postwar sexology heralded by Kinsey demonstrated, at least until the publication of the Male volume, a renewed openness 
to psychoanalytic approaches as one of a number of legitimate scientific approaches to the study of human sexuality. Kinsey was at no stage overwhelmingly propsychoanalytic; there are too many hesitations around psychiatric theory and clinical methods peppering the Reports and his personal correspondence to justify such a claim, especially as the 1950s progressed. Nonetheless, the sources examined here do give cause to temper the "anti-psychoanalytic" claims often levelled against the ISR team, and to venture some larger conclusions about the shifting nature of this crossdisciplinary relationship.

In both a methodological and theoretical sense, the appearance of the Kinsey Reports marked the start of a new divergence between these two increasingly influential fields. While the Reports took some analytic assumptions for granted, such as the existence of prepubertal sexuality, differences between these camps became especially apparent when it came to homosexuality. Kinsey argued that this condition was so widespread that it could hardly be the pathological deformity that many conservative analysts such as Bergler, Bieber, and Socarides were now insisting, even as the latter continued to seek clinical means of "converting” individuals toward heterosexuality. Kinsey differed from midcentury analysts, too, on the relative merits of studying "sex" as a behavioral and biological function in isolation from the psychological packaging of “love.” At the same time, his preparedness to speak at psychoanalytic associations during the late 1940s and early 1950s, his efforts acquire interview subjects through such engagements, and the obvious mutual interest of these psychoanalytic audiences in the Bloomington team's research, points to an equivocal rather than antagonistic relationship during much of the first postwar decade.

Greater conflicts emerged when it came to methodology, reflected both in Kinsey's sharpening tone towards analytic findings between the Male and Female Reports, but also the increasing attacks on his work by conservative analysts. A keen sense of professional competitiveness accelerated the split between these two branches of the human sciences during the decade-and-a-half between 1945 and 1960. As analytic concerns came too dominate psychiatry more strongly than at any other time before or since, Kinsey and his team were busy conquering the US media with their revolutionizing accounts of what Americans really did in bed. With each field striving to affirm its scientific authority, a shift occurred in their professional and disciplinary 
self-understanding that might be characterized as a mutual coming of age. No longer working in close proximity with analytic researchers in the way that his European forebears such as Hirschfeld had done-indeed, deliberately distancing himself from the work of earlier sexologists-Kinsey and his team developed a distinctly modern, technologized and statistical brand of sexual science that diverged starkly from the more subjective clinical mode of the psychoanalytic case study. And yet, even as these positions grew further and further apart, a number of Kinsey’s sexological colleagues, such as Benjamin, continued to engage carefully with psychoanalytic approaches in ways that problematize assumptions of any sharp disciplinary split. This article has argued, then, for a less oppositional appraisal of America's most famous sexologist in relation to one of the most important intellectual and psychiatric movements of the twentieth century. Its findings point to the benefits of pursuing a more interdisciplinary and dialogical history of modern sex research both before and after World War II.

\footnotetext{
${ }^{1}$ Report from Dr. Kinsey (Letter to the editors), Cue, 3 May 1948. Kinsey Institute for Research in Sex, Gender, and Reproduction: Alfred Kinsey Collection, 1920-1947. My thanks to Liana Zhou of the Kinsey Institute library in Bloomington, Indiana for directing my attention towards this source, to Shawn C. Wilson for archival assistance, and to the two reviewers for their most helpful feedback. On Cue magazine’s midcentury reach see Peter Glankoff, “Cue Magazine Paved Way for Arts Guides” [Letter to the Editor, 11 April 1995], New York Times 15 April 1995. URL: http://www.nytimes.com/1995/04/15/opinion/l-cue-magazine-paved-way-for-arts-guides-789496.html. ${ }^{2}$ On Kinsey’s complex relationship with Terman see (Hegarty, 2013) ${ }^{3}$ Kinsey Institute: Kinsey Era Correspondence 1939-1959. Ackerman, N.W. Physician/Sec. for the Association for Psychoanalytic and Psychosomatic Medicine. 1 piece, 1945, NYC. 8 November 1945, NW Ackerman, MD to Alfred C. Kinsey (hereafter ACK).

${ }^{4}$ Kinsey Institute: Kinsey Era Correspondence 1939-1959. Rado, Sandor. Dept of Psychiatry, Director of the Columbia University Psychoanalytic Clinic for Training and Research. 2 November 1945 ACK to Rado.

${ }^{5}$ Ibid: 26 November 1946, Rado to ACK c/o NY Psychoanalytic Institute.

${ }^{6}$ Ibid: 14 April 1947, Mary E Marquette, Clinic Secretary to ACK.

${ }^{7}$ Ibid: 21 April 1947, ACK to Rado.

${ }^{8}$ Ibid: ACK to Mary E Marquette, 10 February 1948.

${ }^{9}$ In 1956 Wardell B. Pomeroy agreed to participate in a panel following Dr Harold Greenwald’s paper “The Call Girl - A Socio-Psychoanalytic Analysis” at Hunter College in New York, although a change
} 
of date meant that he was unable to attend. Association for the Applied Psychoanalysis. Leah Cahan Schaefer, Corresponding Secretary, to Pomeroy, 8 October 1956.

${ }^{10}$ Kinsey Institute: Kinsey Era Correspondence 1939-1959. New York Psychoanalytic Society. Letters from Sidney Kahr (Secretary, New York Psychoanalytic Society) to ACK, 9 April 1946; Emeline P Hayward (Secretary, New York Psychoanalytic Society) to ACK, 17 Jul 1946; ACK to Hayward, 23 July 1946.

${ }^{11}$ Kinsey Institute: Kinsey Era Correspondence 1939-1959. Gutheil, Emil. Association for the Advancement of Psychotherapy. Gutheil (Secretary-Treasurer) to ACK, 12 April 1948.

${ }^{12}$ Kinsey Institute: Kinsey Era Correspondence 1939-1959. Morse, Robert T. President, Washington Psychoanalytic Society. Morse to ACK, 27 April 1948.

${ }^{13}$ Kinsey Institute: Kinsey Era Correspondence 1939-1959. Dubal, Georges, Psychanalyste, Geneva. Dubal to ACK, 31 March 1948.

${ }^{14}$ Kinsey Institute: Kinsey Era Correspondence 1939-1959. Pfister, Maria. Dr. Psycho-hygienist and H. Meng, Professor of Psychohygiene: Meng to ACK, 16 September 1953; ACK to Meng, 15 October 1953.

${ }^{15}$ Kinsey Institute: Kinsey Era Correspondence 1939-1959. Complex. The Magazine of Psychoanalysis and Related Matters: ACK to Complex, 26 October 1950.

${ }^{16}$ Kinsey Institute: Kinsey Era Correspondence 1939-1959. Bacon, Catherine, Institute for Psychoanalysis, Chicago. Bacon to ACK, 21 March 1951.

${ }^{17}$ ACK to Bacon, 26 March 1951

${ }^{18}$ Association for the Advancement of Psychotherapy: Gutheil (President) to ACK, 17 December 1953; Eleanor L. Roehr (Secretary to Dr. Kinsey) to Gutheil, 16 February 1954.

${ }^{19}$ On scientific objectivity see (Daston \& Galison, 2007); on the historical significance of the case study for psychoanalysis and sex research see (Crozier, 2008; Forrester, 1996; Lang, Damousi, \& Lewis, 2017; Sealey, 2011).

${ }^{20}$ Herald Tribune, May 16, 1958, in (Irvine, 1990, pp. 63-64).

${ }^{21}$ John Chapple, Catholic editor of the Ashland, Wisconsin, Daily Press, in telegram to ACK, 21 August, 1953, cited in (Griffith, 2008)

${ }^{22}$ Kinsey Institute: Kinsey Era Correspondence 1939-1959. Takahashi, Tetsu. 10 March 1950, Takahashi to ACK. On Takahashi’s role in Japanese sex research see (McLelland, 2017).

${ }^{23}$ ACK to Takahashi, c/o the Japan Sex Education Society, Tokyo, 23 November 1951. ${ }^{24}$ Ibid.

${ }^{25}$ Kinsey Institute: Kinsey Era Correspondence 1939-1959. American Journal of Psychology. ACK to

Dr Karl M. Dallenbach, Dept of Psychology, U of Texas, Austin, 30 January 1956. 


\section{References}

Alexander, F. (1938). Psychoanalysis Comes of Age. Psychoanalytic Quarterly, 7, 299-306.

Bancroft, J., \& Graham, C. (2014). Sexual Science in the 21st Century: An Evolving Story. In The Institute of Sexology (pp. 14-19). London: Wellcome Collection, part of the Wellcome Trust.

Bauer, H. (2012). Sexology Backward: Hirschfeld, Kinsey and the Reshaping of Sex Research in the 1950s. In H. Bauer \& M. Cook (Eds.), Queer 1950s:

Rethinking Sexuality in the Postwar Years (pp. 133-149). Basingstoke: Palgrave Macmillan.

Bauer, H. (2017). The Hirschfeld Archives: Violence, Death, and Modern Queer Culture. Philadelphia: Temple University Press.

Benjamin, H. (1954). Transvestism and Transsexualism as Psycho-somatic and Somato-psychic Syndromes. American Journal of Psychotherapy, 8(2), 219230.

Bergler, E. (1956). Homosexuality: Disease or Way of Life? New York: Hill and Wang.

Bieber, I., Dince, H. J., Drellich, P. R., \& Grand, et al., M. G. (1962). Homosexuality: A Psychoanalytic Study of Male Homosexuals. New York: Basic.

Bullough, V. L. (1994). Science in the Bedroom: A History of Sex Research. New York: Basic Books.

Burnham, John C. (Ed.). (2012). After Freud Left: A Century of Psychoanalysis in America. Chicago: University of Chicago Press.

Carter, J. (2007). The Heart of Whiteness: Normal Sexuality and Race in America, 1880-1940. Durham and London: Duke University Press.

Chiang, H. (2008). Effecting Science, Affecting Medicine: Homosexuality, the Kinsey Reports, and the Contested Boundaries of Psychopathology in the United States, 1948-1965. Journal of the History of the Behavioural Sciences, 44(4), 300-318.

Crozier, I. (2008). Pillow Talk: Credibility, Trust and the Sexological Case History. History of Science, 46, 375-404.

Cryle, P., \& Stephens, E. (2017). Normality: A Critical Genealogy. Chicago: Chicago University Press.

Daston, L., \& Galison, P. (2007). Objectivity. New York: Zone.

Davidson, A. I. (2001). The Emergence of Sexuality: Historical Epistemology and the Formation of Concepts. Cambridge, MA: Harvard UP.

Dean, T., \& Lane, C. (Eds.). (2001). Homosexuality-Psychoanalysis. Chicago: Chicago University Press.

D’Emilio, J. (1983). Sexual Politics, Sexual Communities: The Making of a Homosexual Minority in the United States, 1950-1970. Chicago: University of Chicago Press.

Drucker, D. J. (2012). “A Most Interesting Chapter in the History of Science”: Intellectual Responses to Alfred Kinsey's "Sexual Behavior in the Human Male.” History of the Human Sciences, 25(1), 75-98.

Drucker, D. J. (2014). The Classification of Sex: Alfred Kinsey and the Organization of Knowledge. Pittsburgh: University of Pittsburgh Press.

Ekins, R. (2005). Science, Politics and Clinical Intervention: Harry Benjamin, Transsexualism and the Problem of Heteronormativity. Sexualities, 8(3), 306328. 
Forrester, J. (1996). If $p$, then what? Thinking in Cases. History of the Human Sciences, 9, 1-25.

Foucault, M. (1998). The History of Sexuality. London: Penguin.

Freud, S. (1962). Three Essays on the Theory of Sexuality (J. Strachey, Trans.). London: Hogarth.

Fromm, E. (1955). Sex and Character: The Kinsey Report Viewed from the Standpoint of Psychoanalysis [1948]. In Jerome Himmelhoch and Sylvia Fleis Fava (Eds.), Sexual Behavioor in American Society: An Appraisal of the First Two Kinsey Reports (pp. 300-311). New York: Norton.

Frosh, S. (2005). Hate and the "Jewish Science": Anti-Semitism, Nazism and Psychoanalysis. Houndmills, Basingstoke: Palgrave Macmillan.

Fuechtner, V. (2011). Berlin Psychoanalytic: Psychoanalysis and Culture in Weimar Republic Germany and Beyond. Berkeley: University of California Press. (16712500).

Fuller, S. (1996). Talking Metaphysical Turkey About Epistemological Chicken and the Poop on Pidgins. In P. Galison \& D. J. Stump (Eds.), The Disunity of Science. Boundaries, Contexts, and Power (pp. 170-186). Stanford: Stanford University Press.

Gherovici, P. (2017). Transgender Psychoanalysis: A Lacanian Perspective on Sexual Difference. London and New York: Routledge.

Giddens, A. (1992). The Transformation of Intimacy Sexuality, Love and Eroticism in Modern Societies. Cambridge: Polity Press.

Gordan, R. (2014, October 28). Orthodox Sex: Alfred Kinsey and the Re-Making of Jewish Sexuality. Retrieved January 31, 2019, from Notches website: http://notchesblog.com/2014/10/28/orthodox-sex-alfred-kinsey-and-the-remaking-of-jewish-sexuality/

Griffith, R. M. (2008). The Religious Encounters of Alfred C. Kinsey. Journal of American History, 95(2), 349-377.

Grossmann, A. (1995). Reforming Sex: The German Movement for Birth Control and Abortion Reform, 1920-1950. New York: Oxford University Press.

Hale, Jr., N. G. (1995). The Rise and Crisis of Psychoanalysis in the United States: Freud and the Americans, 1917-1985. New York: Oxford University Press.

Haraway, D. (1988). Situated Knowledges: The Science Question in Feminism and the Privilege of Partial Perspective. Feminist Studies, 14(3), 575-599.

Hegarty, P. (2013). Gentlemen's Disagreement: Alfred Kinsey, Lewis Terman, and the Sexual Politics of Smart Men. Chicago: University of Chicago Press.

Herzog, D. (2006). The Reception of the Kinsey Reports in Europe. Sexuality \& Culture, 10(1), 39-48.

Herzog, D. (2017). Cold War Freud: Psychoanalysis in an Age of Catastrophes. Cambridge: Cambridge University Press.

Igo, S. E. (2007). The Averaged American: Surveys, Citizens, and the Making of a Mass Public. Cambridge, MA: Harvard University Press.

Irvine, J. (1990). Disorders of Desire: Sex and Gender in Modern American Sexology. Philadelphia: Temple University Press.

Jones, J. H. (1997). Alfred C. Kinsey: A Life. New York and London: W. W. Norton.

Kinsey, A. C., Pomeroy, W. B., \& Martin, C. E. (1948). Sexual Behavior in the Human Male. Philadelphia and London: W. B. Saunders.

Kinsey, A. C., Pomeroy, W. B., Martin, C. E., \& Gebhard, P. H. (1953). Sexual Behavior in the Human Female. Philadelphia and London: W. B. Saunders. 
Kroger, W. S., \& Bergler, E. (1954). Kinsey's Myth of Female Sexuality: The Medical Facts. New York: Grune \& Stratton.

Lang, B., Damousi, J., \& Lewis, A. (2017). A History of the Case Study: Sexology, Psychoanalysis, Literature. Manchester: Manchester University Press.

Lang, B., \& Sutton, K. (2016). The Queer Cases of Psychoanalysis: Rethinking the Scientific Study of Homosexuality, 1890s-1920s. German History, 34(3), 419-444.

Leng, K. (2017). Sexual Politics and Feminist Science: Women Sexologists in Germany, 1900-1933. Ithaca, N.Y.: Cornell University Press.

Lunbeck, E. (2003). Psychiatry. In D. Cahan (Ed.), From Natural Philosophy to the Sciences: Writing the History of Nineteenth-Century Science (pp. 663-677). Chicago: University of Chicago Press.

Makari, G. (2008). Revolution in Mind: The Creation of Psychoanalysis. New York: Harper.

Makari, G. (2012). Mitteleuropa on the Hudson: On the Struggle for American Psychoanalysis after the Anschluß. In Burnham, John C. (Ed.), After Freud Left: A Century of Psychoanalysis in America (pp. 111-124). Chicago: University of Chicago Press.

Masters, W. H., \& Johnson, V. E. (1966). Human Sexual Response. Boston: Little Brown.

McLelland, M. (2017). Takahashi Tetsu and Popular Sexology in Early Postwar Japan, 1945-1970 (pp. 211-231) Mark McLelland. In V. Fuechtner, D. E. Haynes, \& R. M. Jones (Eds.), A Global History of Sexual Science, 18801960 (pp. 211-231). Berkeley: University of California Press.

Meyerowitz, J. (2001). Sex Research at the Borders of Gender: Transvestites, Transsexuals, and Alfred C. Kinsey. Bulletin of the History of Medicine, 75(1), 72-90.

Meyerowitz, J. (2002). How Sex Changed: A History of Transsexuality in the United States. Cambridge, Mass: Harvard University Press.

Minton, H. L. (2010). Departing from Deviance: A History of Homosexual Rights and Emancipatory Science in America. Chicago: University of Chicago Press.

Nitzschke, B., Heigl-Evers, A., \& Heigl, F. (1995). "Wo es in einer Sache nur Gegner oder Anhänger gibt”: Ein bisher unbekannter Brief Sigmund Freuds an Max Marcuse ["Where a matter has only opponents or adherents": A previously unknown letter from Sigmund Freud to Max Marcuse]. Zeitschrift für Sexualforschung [Journal of Sexual Research], 8(3), 241-248.

Pomeroy, W. B. (1972). Dr. Kinsey and the Institute for Sex Research. London: Thomas Nelson \& Sons.

Radó, S. (1940). A Critical Examination of the Concept of Bisexuality. Psychosomatic Medicine, 2, 459-467.

Reumann, M. (2005). American Sexual Character: Sex, Gender, and National Identity in the Kinsey Reports. Berkeley: University of California Press.

Rose, N. (1996). Assembling the Modern Self. In R. Porter (Ed.), Rewriting the Self: Histories from the Renaissance to the Present (pp. 224-248). London: Routledge.

Sealey, A. (2011). The Strange Case of the Freudian Case History: The Role of Long Case Histories in the Development of Psychoanalysis. History of the Human Sciences, 24(1), 36-50.

Sengoopta, C. (2000). Tales from the Vienna Labs: The Eugene Steinach-Harry Benjamin Correspondence. New York Academy of Medicine, (2), 2-7. 
Sigusch, V. (2008). Geschichte der Sexualwissenschaft [History of Sexual Science]. Frankfurt: Campus Verlag.

Socarides, C. (1960). Theoretical and Clinical Aspects of Overt Male Homosexuality. Journal of the American Psychiatric Association, 8, 552-566.

Sutton, K. (2019). Sex between Body and Mind: Psychoanalysis and Sexology in the German-Speaking World 1890s-1930s. Ann Arbor: University of Michigan Press [in press].

Terry, J. (1999). An American Obsession: Science, Medicine, and Homosexuality in Modern Society. Chicago: Chicago University Press.

Thompson, N. L. (2012). The Transformation of Psychoanalysis in America: Emigré Analysts and the New York Psychoanalytic Society and Institute, 1935-1961. Journal of the American Psychoanalytic Association, 60(1), 9-44.

Thompson, N. L., \& Keable, H. (2016). The Psychoanalytic Study of the Child: A Narrative of Postwar Psychoanalysis. American Imago, 73(3), 343-382.

Trask, A. (2018). Remaking Men: Masculinity, Homosexuality and Constitutional Medicine in Germany, 1914-1933. German History, 36(2), 181-206.

Wake, N. (2011). Private Practices: Harry Stack Sullivan, the Science of Homosexuality, and American Liberalism. New Brunswick: Rutgers University Press.

Weber, B. (2010). Talking Sex, Talking Kinsey. Australian Feminist Studies, 25(64), 189-198.

Zaretsky, E. (2004). Secrets of the Soul: A Social and Cultural History of Psychoanalysis. New York: Vintage. 